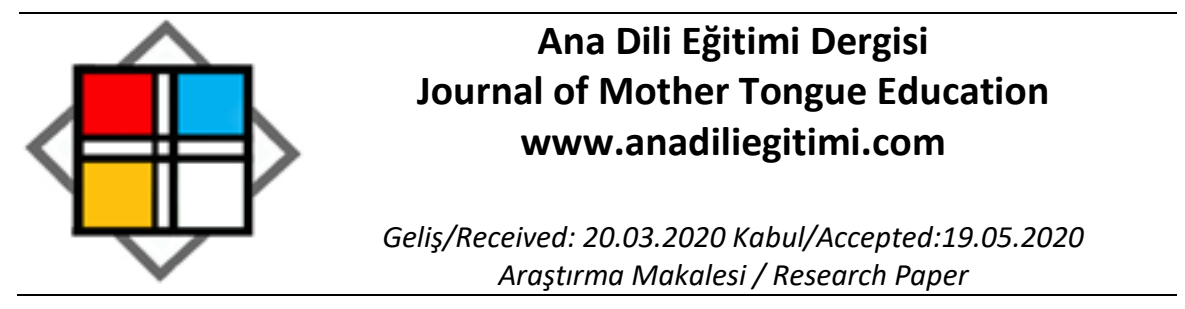

\title{
Çocuk Edebiyatında Bir Anlatı Türü Olarak Mektup*
}

\begin{abstract}
Evren KARATAŞ**
Öz

Günümüzde her ne kadar genel ağın etkisiyle büyük oranda biçimsel değişikliklere uğrasa ve itibarını yitirse de mektup türü içtenliği ve öznelliği iyi ifade eden bir iletişim aracı olarak çağlar boyunca varlık göstermiştir. Mektup türü sadece birbirinden uzakta bulunan kişiler arasında haber getirip götüren bir tür değil, aynı zamanda birçok tarihî ve sosyal meselenin de çözüme ulaştırılmaya çalışıldığı diplomatik metinlerdir. Mektup yetişkin edebiyatında olduğu gibi çocuk edebiyatında da çok tercih edilen bir tür olmamıştır. Aslında mektup türü içten ve kişisel bir anlatım içerdiğinden çocuğun dünyasına çok uygun bir türdür. Ayrıca çocuk kendini dünya karşısında tanımlama döneminde olduğundan bu amaca uygun bir tür olan mektubu da severek yazabilecek/okuyabilecek yaşlardadır. Çalışmada mektup türündeki Türkçe ve çeviri şu eserler araştırmanın inceleme nesneleri olarak seçilmiştir: Hidayet Karakuş-Annemin Mektupları, Hasan Yalçın-Gül'e Mektuplar ve Yıldızlı Masallar, Bill Adler-Çocuklardan Harry Potter'a Mektuplar, Eric Marshall, Stuart Hample-Çocuklardan Tanrıya Mektuplar, Mavisel Yener- Dehşet Mektuplar/Dolunay Dedektifleri 2 ve Hayaletten Mektuplar, Çiler Çelikten- Hayvanlardan Çocuklara Mektuplar I ve II, Aziz Nesin-Şimdiki Çocuklar Harika ve Zehra İpşiroğlu-Şimdiki Çocuklar Hâlâ Harika. Çalışmanın bulguları durum çalışması yöntemiyle elde edilmiş, veriler içerik analiziyle değerlendirilmeye çalışılmıştır. Sonuç olarak mektup türünün çocuk edebiyatı ürünlerinde daha çok eğitici bir nitelik taşıdığı, çocuğun içten ve doğal bir anlatım diline sahip olmasında yararları olduğu belirlenmiştir.
\end{abstract}

Anahtar Sözcükler: Çocuk edebiyatı, çocuk ve mektup, öznel anlatım, edebî tür

\begin{abstract}
Today, although it undergoes formal changes drastically and falls from grace with the effect of the internet, the letter form has existed for ages as a communication tool which expresses faithfullness and subjectivity well. The letter form is not only a form of receiving and sending news between people who are far from each other, it is also a diplomatic text in which many historical and social problems are get solution. The letter form is not preferred much in child literature as it is not in adult literature. Moreover, as the child is in the time of defining himself/herself against the world, he/she is also at the age of writing or reading this type which supports this aim. In this study which are written in Turkish or translated into Turkish given below are chosen: Hidayet Karakuş-Annemin Mektupları, Hasan Yalçın-Gül'e Mektuplar ve Yıldızlı Masallar, Bill Adler-Çocuklardan Harry Potter'a Mektuplar, Eric Marshall, Stuart Hample-Çocuklardan Tanrıya Mektuplar, Mavisel Yener- Dehşet Mektuplar/Dolunay Dedektifleri 2 ve Hayaletten Mektuplar, Çiler Çelikten- Hayvanlardan Çocuklara Mektuplar I ve II., Aziz Nesin-Şimdiki Çocuklar Harika ve Zehra İpşiroğlu-Şimdiki Çocukar Hâlâ Harika. The findings of the study are obtained by the case study method and the data is evaulated by the content analysis. Finally, it is seen that the letter form has an educative effect on children and it provides benefit for children to have a faithful and natural narrating skill.

Keywords: Child literature, child and letter, faithful and natural narrating skill, literary genre
\end{abstract}

Letter as a Type of Narrative in Children's Literature

\footnotetext{
* Bu makale, 05-07 Ekim 2011 tarihleri aralığında, Ankara'da düzenlenmiş olan III. Ulusal Çocuk ve Gençlik Edebiyatı Sempozyumu'nda sunulan "Çocuk Edebiyatında Bir Anlatı Türü Olarak Mektup" başlıklı sözlü bildirinin genişletilmiş ve yeniden düzenlenmiş hâlidir.

** Dr. Öğr. Üyesi, Cumhuriyet Üniversitesi Eğitim Fakültesi, Türkçe ve Sosyal Bilimler Eğitimi Bölümü, Sivas, ekaratas@cumhuriyet.edu.tr. ORCID: https://orcid.org/0000-0001-6598-5080
} 


\section{Giriş}

Illetişim insanoğlunun zorunlu gereksinimlerinden biridir. Insanlar yüz yüze iletişim kuramadıkları kişilere çeşitli haberleri, duygularını ve düşüncelerini aktarmak için farklı yollar denemişlerdir. Mektup ise bu deneme çabalarından belki de en geliş̧sişidir. illk dönem mektupları özel olmaktan daha çok resmî bir dille yazıımışlardır. Siyasî, sosyal, edebî pek çok konunun tartışıldığı bu mektuplar arasında Firavun Mektupları, Eflatun ve Cicero'nun mektupları sayılabilir. Yine ilk dönemde mektupların eğitici bir boyut taşıdığı da bilinmektedir. Özellikle İslâm dünyasında mektupların tasavvufî ve eğitici bir nitelik taşıdıkları görülür. Bu açıdan Mevlâna'nın, Rabbani'nin ve İmam Gazali'nin mektupları bugün de büyük değer taşımaktadır. Eski Yunan ve Latin geleneği içerisinde mektupların hiciv yönünden de gelişmiş olduklarını belirtmek gerekir. Özel mektupların gelişmesi ancak "bireyselliğin" öne çıkması ve romantizm akımının güçlenmesiyle sağlanır. Özel mektupçuluğun bu parlak dönemi 18. yüzyıla rast gelir. Thomas More'un Londra Kalesi'ndeki tutsaklığı sırasında kızı Margaret'e bir kömür parçasıyla yazdığı mektup bir edebiyatçının elinden çıkmış ilk özel mektup olarak kabul görmektedir. (Kefeli, 2002: 9-13). Görüldüğü üzere ilk özel edebî mektup da bir çocuğa yazılmıştır. $O$ günden bugüne kadar bir kısmı yazarların yaşadıkları dönemde, bir kısmı ise ölümlerinden sonra yayımlanmış büyük bir mektup külliyatı bulunmaktadır. Ancak edebî sahada mektubun tahkiyeli türlere oranla daha az kullanıldığı görülür. Bunun yanı sıra kurgusal metinlerde bir anlatım tekniği olarak mektuptan yararlanılan eserler ve mektup romanlar da bulunmaktadır.

Mektup çocuk edebiyatında bugüne kadar inmal edilmiş bir türdür. Çocuk edebiyatında mektup türündeki eserlerin nicelik bakımından azlığı bu konu üzerine yazılmış akademik yayınları da etkilemiş̧ir ${ }^{1}$. Çocuk edebiyatı sahasında anılmasa da Ziya Gökalp ve Namık Kemal'in sürgünden çocuklarına yazdıkları mektuplar, batılı anlamda türün ilk örnekleri olması bakımından önemlidir. Namık Kemal'in kızı Feride ve oğlu Ekrem'e yazdığı mektuplar ile Ziya Gökalp'ın kızları Seniye, Hürriyet ve Türkan'a yazdığı mektuplar dönemin çocuk terbiyesi ve sosyal bağlamda çocukluk kavramlarının metinler üzerinden okunmasında oldukça yararlı metinlerdir. Her iki yazarın da bu mektuplarında çocuklarının eğitimi üzerinde önemle durdukları görülür (Energin Usta, 2010: 1104-1105). Namık Kemal oğlu Ekrem'e hitaben mektubun ayrı düşenleri kavuşturma yolunda önemli bir araç olduğunu belirterek oğlunu şu sözlerle mektup yazmaya güdülemektedir: “"Midilli'ye gelmek zor bir şey değildir. Fakat senin gibi çocukları babalarının yanına götürmek için yeni bir gemi icad etmişler; direkleri kalemden, yelkenleri kâğıttan imiş. Sen de elindeki kalemi, kâğıdı direk, yelken yapabilirsen, yanıma pek çabuk gelebilirsin" (Aktaran: (Energin Usta, 2010: 1104; Tansel, 1986: 45).

Namık Kemal, kızı Feride'ye 27 Nisan 1878 tarihinde Midilli'den gönderdiği mektubunda şöyle seslenir: "İnsanlar içinde yazıyı, bizim mülkte kız mekteplerini icadeden zâtlara günde bir kerre rahmet okusam, gönlüm müteselli olmayacak. Bereket versin o sayede mektuplarını alıyorum; gönlüm rahat ediyor" (2013:150). Bu sesleniş kız çocuklarının eğitim alması yönünde şairin ne denli kuvvetli bir fikre sahip olduğunu göstermesi bakımından önemlidir

Ziya Gökalp'ın Limni ve Malta'dan kızlarına yazdığı mektupların ana konusunu eğitim oluşturur. O döneme göre "ileri" bir düşünce örneği olarak, kız ve erkek çocuk arasında eşitlik bulunduğunu vurgulayan Gökalp, kız çocuklarının eğitimi konusuna ayrı bir önem verir ve onlara yazdığı her mektubunda yabancı dil öğrenmenin, kitap okumanın ve genel kültürün öneminden bahseder. Örneğin 30 Ekim 1919 tarihli Polverista'dan gelen ve "Kızlarım Seniha, Hürriyet ve Türkan Hanımlar'a” hitabıyla başlayan mektubunda Ziya Gökalp çocuklarına şöyle seslenir:

"Bir çocuk için en faydalı şey kendi istidâdını tanımaktır. Hangi hünere istidâdı olduğunu bilen ve en çok istidâtlı olduğu ilme çalışan talebe muvaffak olur. Hisap, hendese gibi ilimler akla kuvvet verir. Bir de insan hisap ve hendesedeki meseleleri hallederken, dâvaları ispat ederken büyük bir zevk duyar. Çocuklar bilmece oyununa çok meraklıdır. İşte hisapla hendese, ilmin bilmeceli bir kısmıdır ve ileride okunacak hikmet gibi, kimya gibi ilimlerin de temelidir. $O$ halde bu iki derse büyük bir ehemmiyet vermek lâzım. Hisapla hendeseden sonra, edebiyat ve şiire kıymet vermeli; çünki bu iki hüner de gayet

\footnotetext{
${ }^{1}$ Baş, 6. sınıf Türkçe ders kitaplarında yer alan edebî türler üzerine yaptığı araştırmasında mektup türünün hem Millî Eğitim Bakanlığı tarafından hem de özel yayınevlerince hazırlanan kitaplarda sadece birer metinle temsil edildiğini tespit etmiştir (2003: 262-263).
} 
eğlenceli ve zevklidir. Aynı zamanda zekâya nur, muhayyeleye kanat, kalbe de heyecan verir. Derslerin en vecdlisi, edebiyata ve şiire dair olanlardır. Resimle mûsıkî de şiirle edebiyatın arkadaşıdır. Bunların hepsi ruha güzellik, ahlaka temizlik verir. İnsan en tatlı vecdleri bu hünerlerden alır. Din ve ahlak dersleri de en vecdli derslerdir. (...) Hâsılı derslerinize bir oyun gibi, eğlence gibi çalışınız ve en ziyade akla, kalbe kuvvet veren, ruhu vecdlerle dolduran derslere çalışınız. Bu yolda yürürseniz içi dışı bir samimi insanlardan olursunuz" (1965:73).

Yabancı dil bilmelerinin gerekliliği konusunu ise Ziya Gökalp çocuklarına 6 Kasım 1919 tarihinde Polverista'dan gönderdiği mektubunda şu şekilde açıklar: “Halkın iyi gördüğü şeyi Hak da iyi görür; fakat medeniyete gelince, bunu katiyyen halktan alamayız; çünki medeniyet ilimdir, fendir, sanayidir. 0 halde medeniyeti ilimde, fende, sanayide çok ileri gitmiş memleketlerden, yani Avrupa'dan almamız icabediyor. Avrupa'dan medeniyeti almak için de her Türk'ün Avrupa lisanlarından birini bilmesi lâzımdır. Biz Türk ve Müslüman kalmak şartıyle, Avrupalı bir millet olmaya çalışmalıyız. Gayemiz, Avrupa medeniyeti içinde bir Türk harsı yaratmak olmalıdır. İşte bundan dolayıdır ki, Fransızca çalışıp çalışmadığınızı sordum; çünki sizin de Avrupa lisanlarından birini bilmeniz lazımdır" (1965: 79). Mektuplarda çocuk ile masal, oyun, ana dili eğitimi ve beden sağlığı ilişkilerine sıkça vurgu yapıldığı görülür. Gökalp daha on bir aylık olan kızı Türkan'a yazdığı mektuplarda ise farklı bir dil kullanarak ona ulaşmaya çalışır, eşi Vecihe Hanım'a da Türkan'a masal ve oyun yoluyla eğitim vermelerinin daha uygun olacağını belirtir (Argunşah, 1996)

Çocuk edebiyatı üzerinde yazılmış akademik çalışmaların çoğunda mektup türünün çocuğa uygun türler arasında yer almaması dikkat çekmekle birlikte alan yazında az da olsa çocuk ve mektup konusuna değinmiş araştırmacılar da bulunmaktadır. ${ }^{2}$ Bu kuramcılardan biri de Alev Sınar Çılgın'dır. Sınar Çılgın, çocuk edebiyatında bu türde pek fazla eser olmadığını belirtmekte ancak bu türün çocuk için elverişli türlerden biri olduğunu da vurgulamaktadır. Sınar Çılgın, mektubun çocuk için "duygularını samimi bir şekilde aktarmasına, deşarj olmasına, ilişkileri sağlamlaştırmasına, mektubun yazıldığı kişinin hayatımızdaki yerini sorgulamasına, özlem ve sabır duygularını öğrenmesine vesile olan iyi bir yazılı anlatım yolu olduğunu vurgulamaktadır" (2007: 169). Sınar Çılgın'a göre tüm bu nedenlerden dolayı hem çocuklar için mektup türünde eserler üretmekte hem de onları mektup yazmaya teşvik etmekte yarar vardır.

Çerçi ise mektup türünün çocuklar için önemi hakkında şöyle düşünmektedir: "Mektup, çocuklara okuma alışkanlığı kazandırımasında, çocuğun yazılı olarak duygu ve düşüncelerini ifade edebilmesinde ve kendisini başkalarının yerine koyarak düşünme becerisinin gelişmesinde, iletişim becerilerinin güçlenerek kendisini daha içten, daha rahat ifade edebilmesinde oldukça önemli bir türdür" (2019:23).Kanonik edebiyat bağlamında da mektup türünün diğer türlere oranla ihmal edildiğini gözlemlemek mümkündür. Ülkemizde kanonik edebiyatın en ikonik görünümlerinden biri olan İlköğretim Yüz Temel Eser bağlamında türe yaklaşıldığında da durumun mektup lehine olmadığı görülür. Zira İlköğretim Yüz Temel Eser içerisinde mektup türünde yazılmış hiçbir eser yoktur. Bugün yürürlükte olmayan illköğretim Yüz Temel Eserin tür konusu açısından eleştirisi bir başka yazının konusu olacak genişliktedir. Ancak seçilen eserler üzerinde yapılacak basit bir istatistik hesaplama bile türler açısından oldukça dar bir alana hitap edildiği yönünde olacaktır. İlköğretim Yüz Temel Eser seçkisi içerisinde çokça yer alan türler roman ve öyküdür. Bunu masal ve şiir türleri takip etmektedir. Anı, gezi yazısı, deneme gibi türler ise birer eser ile listede temsil edilmektedir. Bu durum çeviri yayınlarda daha da olumsuz bir görünüm kazanmıştır. Bu gruptaki kitapların hepsi de kurgusal türlerdendir (masal, öykü, roman). Ortaöğretim Yüz Temel Eser seçkisi içerisinde Ahmet Rasim'in Şehir Mektupları adlı eseri yer almakla birlikte bu eserin aslında mektup türünde yazılmadığını, çalışmanın tür olarak sınıflandırılmasının zor olduğunu da belirtmekte vardır. Sohbet, fıkra türüne daha yakın olan eserin Ahmet Rasim'in İstanbul üzerine yazdığı köşe yazılarının bir araya getirilmesiyle oluşturulduğu

\footnotetext{
${ }^{2}$ Mektubu bir çocuk edebiyatı türü olarak değerlendiren çalışmalar ise şunlardır: Alev Sınar Çılgın (2007). Çocuk Edebiyatı. İstanbul: Morpa Yayınları. Ömer Yılar, Lokman Turan(Ed.) (2007) Eğitim Fakülteleri İçin Çocuk Edebiyatı. Ankara: Pegem A, adlı çalışmada ise mektup “Çocuk Edebiyatının Kaynakları/Meraka Dayalı Türler” başlığı altında ele alınmıştır. Tacettin Şimşek (2004). Çocuk Edebiyatı. Erzurum: Suna Yayınları., Hasan Güleryüz (2006). Yaratıcı Çocuk Edebiyatı. Ankara: Pegem A Yayıncılık.
} 
bilinmektedir. Ortaöğretim Yüz Temel Eser seçkisinde de kurmaca türlerin görece ağırlıkta olması da dikkat çekmektedir. Zaten her iki seçki de günümüzde geçmişteki kadar ilgi görmemektedir.

Donbay çocuk edebiyatı alanında mektup türünde yazılmış eserleri şu şekilde sıralamıştır. "Gerek anlatım tekniği gerekse kitap adı olarak mektubun seçildiği yerli ve yabancı çocuk ve gençlik edebiyatı eserlerinden bazıları şunlardır: Eflatun Cem Güney, Zindandan Gelen Mektup ve Düşmez Kalkmaz Bir Allah (1970); Mustafa Ruhi Şirin, Masal Mektuplar (1983); Güngör Tekçe, Büyüklere Kuşlu Mektuplar (1996) ve Kuşlu Mektuplarım Döndü (1996); Gülten Dayıoğlu, Ece'den Mektup Geldi-Ece ile Yüce (1998); İpek Ongun, Mektup Arkadaşları (1999); Bahar Vardarlı, Su ile Pınar'ın Mektupları (2000); Hidayet Karakuş, Annemin Mektupları (2001); Sevim Ak, Vanilya Kokulu Mektuplar (2002); Mavisel Yener, Dolunay Dedektifleri 2: Dehşet Mektupları (2010); J. R. R. Tolkien, Noel Baba'dan Mektuplar (2005), Bill Adler, Çocuklardan Harry Potter'a Mektuplar (2006)" (2011:100).

Çocuk edebiyatında yakın dönemlere kadar mektup türünde yazılan ve önerilen kitaplar arasında Aziz Nesin'in Şimdiki Çocuklar Harika, Cahit Uçuk' un Bahçemden Mektuplar ile Mustafa Ruhi Şirin'in Masal Mektuplar gösterilmektedir (Sınar Çılgın, 2007: 169). Bu çalışmada nitel araştırmalardan durum çalışması (veya temel nitel desen) ile oluşturulan araştırmanın inceleme nesneleri 2000 yılından sonra yazılmış yerli/yabancı dokuz çocuk kitabıdır. Araştırmanın yöntemi, durum çalışmasının alt desenlerinden iç içe geçmiş tek durum desenidir. Veriler doküman incelemesi ile toplanmış, içerik analizi ile değerlendirilmiştir.

Bu eserlerden yedi tanesi kurgusal biçimde oluşturulmuş iki tanesi ise (Çocuklardan Tanrı'ya Mektuplar, Çocuklardan Harry Potter'a Mektuplar) bir tema etrafında çocukların gönderdikleri mektupların bir araya getirilmesiyle oluşturulmuştur. Mektup tekniği kurgusal metinlerde iki biçimde kullanılır. Metin ya art arda gelen mektupların toplamı biçiminde oluşturulur, ya da metin içerisinde yeri geldikçe mektuplara yer verilir (Tekin, 2013: 247). Çalışmada yer alan kitaplardan Hayvanlardan Çocuklara Mektuplar I ve II, Gül'e Mektuplar ve Yıldızlı Masallar, Hayaletten Mektuplar, Annemin Mektupları adlı kitaplarda mektuplar art arda sıralanmış, Dolunay Dedektifleri/Dehşet Mektuplar ve Çocuk Kalbi'nde ise kurguya uygun yerlerde mektuplara yer verilmiştir. Çalışmada bu eserlerin yanı sıra ilk basımı 1967 yılında yapılan Aziz Nesin'in Şimdiki Çocuklar Harika adlı eseri de incelemeye konu edilmiştir. Zira, Zehra İpşiroğlu'nun Şimdiki Çocuklar Hâlâ Harika başlıklı çalışması Aziz Nesin'in adı geçen kitabına nazire niteliğinde kaleme alındığından, biçim ve kurgu açısından Aziz Nesin'in eserinin bir nevi devamı niteliğinde bir nehir roman hüviyeti taşıdığından Aziz Nesin'in Şimdiki Çocuklar Harika adlı eserinin de tarihsel örneklem filtresine uymamakla birlikte kısa da olsa değerlendirme konusunu yapılmasının yararlı olacağı düşünülmüştür. Bu bağlamda, her iki eserin de art arda sıralanmış mektuplar şeklinde oluşturulmuş birer mektup roman olduğu görülmüştür. Sonuçta çalışmaya eklenen bu iki eser ile birlikte araştırmanın inceleme nesnelerini toplam on bir eser oluşturmuştur.

\section{Mektup Türündeki Yerli Çocuk Edebiyatı Ürünleri Annemin Mektupları}

Hidayet Karakuş'un Annemin Mektupları adlı eserinde, işe gittiği için oğlunu yeterince göremeyen bir annenin 2000 yılının bahar aylarında, oğluna hitaben yazdığı dört mektuba yer verilmiştir. Anne "Tahta Bisiklet" adını taşıyan ilk mektubunda kendi çocukluk yıllarından bir anısına yer verir. Bu mektupta yazar ekonomik sorunlar ve buna bağlı göç konusu çerçevesinde bir babanın kızı için bulduğu yaratıcı oyuncak yapımı çözümünü çocuk okurlarla paylaşır (Karakuş, 2009: 10-22). Kız çocuk bu oyuncak ile pek oynayamasa da onu, babasının sevgisinin göstergesi olarak kabul eder. Mektup zor günlerin birlik içinde aşılabileceğini ve sevginin her şeyden daha değerli olduğunu ortaya koyması açısından önemlidir. "Eski Çanta" başlıklı ikinci mektupta anne oğluna yalnız geçen çocukluk yıllarını ve o yıllarda kurguladığı oyunları, bu oyunlarla bir çocuğun dünyayı ve yaşamı nasıl keşfetmeye başladığını anlatmaktadır. Ne de olsa oyun çocuğun merceğidir; çocuk oyunla algılar, yetkinleşir ve öğrenir (Karakuş, 2009: 23-35). Üçüncü mektup "Ben Ne Olayım?” başlığına sahiptir (Karakuş, 2009: 36-51). Mektupta ne olmak istediğine bir türlü karar veremeyen ve hayvanların güçlü yönlerine öykünerek onlar gibi olmaya çalışan ancak bundan da kısa sürede sıkılan kız çocuğunun duygu hâli anlatılmaktadır. Mektup sonuç olarak, en iyi yolun insanın kendini olduğu gibi kabul etmesi ve farklı 
yönlerini keşfedip geliştirebilmesi olduğu iletisini aktarmaktadır. "Kasabamızın Köpekleri” adlı son mektupta ise yazar hem hayvan sevgisini hem de sabır ve azim kavramlarını çocuklara aktarmaya çalışır. Animistik dönem özellikleri taşıyan çocuk bu dönemde pek çok hayvana öykünür, zamanla insan olmanın bilincine ulaşan çocuk doğanın sadece insanın değil, her canlının evi olduğu gerçeğini daha o yaşlarda fark eder. Eser çevre okur yazarlığı ve ekoeleştiri açısından da zengin bir birikim içermektedir.

\section{Dehşet Mektuplar/ Dolunay Dedektifleri-2}

Mavisel Yener'in Dehşet Mektuplar/ Dolunay Dedektifleri-2 adlı kitabı, adından da anlaşılacağı üzere polisiye türünde bir çocuk edebiyatı metnidir. Kurgu içerisinde aralıklarla verilen üç adet mektup, eserde entrika düğümlerinin oluşturulmasına ve gizem atmosferinin yaratılmasına katkı sağlamaktadır. Uluslararası bir döngüde işlenen kurguda, Birce'nin bir sahaftan tesadüf eseri aldığı kitabın içinden çıkan, Brail alfabesiyle ve Almanca olarak yazılmış mektubun gizemi ancak İspanya'da çözülebilecektir. Genetik bilimci Brickel tarafından Türk meslektaşına yazılan ve bilimsel kodlar ve DNA şifreleri içeren mektuplar Birce, Ece, Ada, Bilgecan, Oğuz ve Gago ve Jutta'nın yardımlarıyla kötü amaçlı kullanımlardan kurtarılarak polislere teslim edilir (Yener, 2010: 89-92). Eser bilimsel merakın yanı sıra arkadaşlık kavramını, polisiye tarzdaki sürükleyici bir anlatımla aktarması sayesinde çocuk okur için hem zengin bir içerik oluşturmakta hem de okuma alışkanlığının geliştirilmesi bağlamında katkı sağlamaktadır.

\section{Gül'e Mektuplar ve Yıldızlı Masallar}

Hasan Yalçın'ın Gül'e Mektuplar ve Yıldızlı Masallar adlı çalışmasında toplam otuz mektup ve otuz yedi adet de masal, bilmece, günlük, öykü, fıkra, şiir ve fabl türünde metin yer almaktadır. Kitapta yer alan öykülerden biri Çehov'dan (Kaştanka), ikisi ise Kafka'dan (Kısa Bir Hayvan Masalı, Açgözlü Kurt) uyarlanmıştır. Yazarın mektup başta olmak üzere pek çok farklı metin türüne yer verdiği eser, çocuk okur için farklı türlerin bir metin içerisinde hızlıca tanıtılmasına olanak veren ve bu açıdan da az rastlanılan bir metinlerarasılık özelliği de taşımaktadır.

Hasan Yalçın'ın tutuklu bulunduğu cezaevinden kızı Gül Yalçın’a 1982-1986 yılları aralığında yazdığı mektuplardan oluşan eserde uzaktaki bir babanın küçük bir çocuğa seslenişine tanık olmak mümkündür. Gül Yalçın'ın 3-7 yaş aralığında olduğu bir döneme karşlık gelen mektuplar bu nedenle okul öncesi dönemdeki bir çocuğa uygun bir üslûpla kaleme alınmış ve çoğu mektup hayvanların kişileştirildiği fabllarla zenginleştirilmiştir. Bu nedenle mektuplarda öğreticilik boyutunun da önemsendiği görülür. Gül Yalçın eserin sunuş bölümünde bu durumun kendi üzerinde bıraktığı etkiyi şöyle dile getirir: “... Dönüp geriye baktığımda, daha iyi değerlendirebiliyorum bu mektupların hayatımdaki yerini. Hayal gücümü genişleten, bana kitap okumayı, edebiyatı sevdiren, dil yeteneğimi geliştiren, olayları değerlendirmeyi ve yargılamayı öğreten ve her şeyin ötesinde bana sonsuz bir insan ve doğa sevgisi kazandıran yazılardı bunlar" (Yalçın, 2006: 9-10).

Mektup ve masallarda özgürlük, hayvan hakları, dostluk ve sevgi, paylaşım, adalet, bilimsel bakış açısı, yardımseverlik, sorumluluk bilinci, doğa sevgisi, aile sevgisi, dayanışma, kahramanlık ve cesaret, haksızlıklara karşı çıkabilme, özlem, zorbalıklara karşı birlikte mücadele edebilme, nedensiz korkuların üstüne gidebilmek, canlıların iç güzelliklerini fark edebilmek ve eşitlik değerlerinin işlendiği görülmektedir.

\section{Hayaletten Mektuplar}

Mavisel Yener'in Hayaletten Mektuplar adlı eserinin iki bölümü mektuplara ayrılmıştır. On bir mektuptan oluşan ilk bölümde Meltem'in başka bir kente taşınması üzerine Figen ile Meltem arasında başlayan mektuplaşma, daha çok iki arkadaşın gündelik yaşamlarını ve Figen'in planladığı İspanya seyahatinin detaylarını içermektedir (Yener, 2009: 43-70). Kitabın ikinci bölümü yine Alper ile Barselona'ya taşınan dayısı arasında gidip gelen on bir mektuptan oluşur. Görüleceği üzere bu iki bölümü birbirine bağlayan ana unsur İspanya'dır. Figen ile Alper İspanya yolculuğu sırasında tanışırlar. (Yener, 2009: 53-55). Eser uzaktaki yakınlıkları korumanın iyi yollarından birinin de mektup yazmak olduğu konusunda çocukları özendirici bir değer taşır. Zira daha sonra Figen ve Alper de uzun yıllar sürecek olan bir mektup arkadaşlı̆ıına başlarlar. Eser aynı zamanda farklı ülkelerin, farklı coğrafyaların 
tarihi köklerini, doğal güzelliklerini ve kültürlerini mektuplar aracıllı̆ıyla yakınlarla paylaşma açısından da öğretici bir değer taşımakta ve çocuk okurların dünya bilgilerini artırmaktadır.

\section{Hayvanlardan Çocuklara Mektuplar Hayvanlardan Cocuklara Mektuplar I}

Hayvanlardan Çocuklara Masallar-l'de yer alan dokuz mektuptan ilki, karınca tarafından çocuğa hitaben yazıımıştır. Mektupta karınca insanların ve doğanın çıkardığı tüm zorluklara karşı birlik içinde yaşadıklarını, ayrıca küçük olsun büyük olsun yeryüzünde her canlının bir görevi ve önemi olduğunu vurgulamaktadır (Çelikler: 2010: 15-18). Diğer mektuplarda ise hayatın bir yarış olmadığı, çocuk eğitiminde kararlııı̆ın önemi, her canlının yaşııık dönemi geçireceği ve herkesin yaşamında aşması gereken zor dönemler olduğu, çocukların gelip geçici hevesler için hayvan sahibi olmamaları gerektiği ve hayvan sahiplerinin onlara iyi bakmakla yükümlü oldukları, kendilik bilinci, sokak hayvanlarına karşı insanların duyarlı olmaları gerektiği mesajlarını içeren konular işlenmiştir. (Çelikler, 2010: 61-64). Kitapta dokuzuncu ve son mektup yavru bir Caretta Caretta'ya aittir. Mektupta soyları tükenme riskiyle karşı karşıya olan hayvanlar için insanların yapmaları gerekenler anlatılmaktadır (Çelikler: 2010: 67-69). Görüldüğü üzere eser, çocukların dünya bilgilerinin artırılması ve kendilik bilinçlerinin gelişmesi ve giderek değişen dünya dengelerine özellikle de doğanın dengesine ayak uydurarak sadece insanın değil tüm canlıların haklarına saygılı olmaları gerektiği yönünde kuvvetli mesajlar içermektedir.

\section{Hayvanlardan Çocuklara Mektuplar II}

Hayvanlardan Çocuklara Mektuplar II- adlı kitaptaki ilk mektup kırlangıçtan çocuğa yazılmıştır. Kırlangıç mektubunda küresel ısınma nedeniyle çektiği sıkıntılardan, iklim değişikliğinden, doğanın küçük bir öğesindeki bozulmanın zincirleme olarak tüm gezegenin dengesini bozmasından söz etmektedir. (Çelikler, 2010: 15-18). Diğer mektuplarda ise sırasıyla iletişim olanaklarının artmasıyla birlikte yüz yüze iletişimin azalması, medya okur yazarlığı, su kaynaklarının tutumlu kullanılması, hayvanların gösteri amaçlı işlerde nesneleştirilmemeleri ve ağır işlerde çalıştırılmamaları gerektiği, zevk için avlanmanın etik dışı oluşu ve depremin ön görülemeyen bir doğa olayı olması ve depreme karşı eğitimli ve hazırlı olmak gerektiği konuları ele alınmıştır. Son mektupta ise çarpık kentleşme, gecekondulaşma, ormanların yok edilmesi gibi nedenlerle sel felaketlerinin arttığına dikkat çekilmektedir (Çelikler, 2010: 75-79). Görüldüğg̈ü üzere Çelikler eserinde çocuk okurlara zengin bir doğa içeriği sunmakta, doğaya duyarlılık noktasında örnekler vermekte ve son dönemlerin önemli kavramı "sürdürülebilirlik"in nasıl işlemesi gerektiğini anlatmaktadır.

\section{Şimdiki Çocuklar Harika}

İki eski okul arkadaşı olan Ahmet ve Zeynep arasında süregelen ve İstanbul Ankara hattında gelişen mektuplaşmalar ilk olarak 12 Kasım 1963 tarihinde başlamıştır. Toplam yirmi dokuz mektuptan oluşan eserin son bölümünde yazar Aziz Nesin'in çocuklara yazdığı iki mektuba daha yer verilmiş ve mektup sayısı bu haliyle otuz bire yükselmiştir. Babasının görevi nedeniyle dönem ortasında dört yıldır birlikte eğitim gördüğü arkadaşlarından ayrı kalmak zorunda kalan ve Ankara'ya yerleşen Zeynep mektuplaşmayı başlatan kişidir. Her iki çocuk mektuplarında yoğun olarak eğitim sistemi ve toplumun ikircikli değer yargılarını mizahi bir dille eleştirmişlerdir. Eleştiri nesnesi haline getirilen konuların mizahî bir perspektiften sunulması hem eleştirinin daha çarpıcı hâle gelerek vurucu bir etki yaratmasını hem de çocuk okurlar için keyifli bir okuma süreci oluşmasını sağlamıştır. Aşağıda, Zeynep'in sınıfta arkadaşı Yaşar ile öğretmeni arasında geçen diyaloğu, Ahmet'e aktarırken kullandığı mizahi dil, toplumun bakışındaki çarpıklığı mizahın ironisiyle güçlü bir biçimde sunmakta ve çocuk okur için eleştirel bir düşünme zemini oluşturmaktadır. Bu diyalog toplumsal cinsiyet kodlarının çocuklar üzerindeki etkisini ortaya koyması ve düşündürmesi açısından dikkate değerdir:

(Öğretmen) "-Cumhuriyet kurulduktan sonra kadınla erkek artık eşit olmuştur. Kadınla erkek arasında hiçbir fark yoktur, dedi. Hiçbir fark olmamasını erkekliğine yediremeyen Yaşar,

-Hiç mi fark yok öğretmenim? dedi.

-Yok

-Küçücük bir fark da mı yok? 
Öğretmen sert

-Yok! dedi.

Yaşar,

Evet ama öğretmenim, dedi. Kadın Haklarını Koruma Derneği var, oysa erkekler böyle bir dernek kurmamışlar. Annem, Kadın Haklarını Koruma Derneği'ne üye..." (Nesin,2008: 84).

Mektuplarda gelir dağılımındaki eşitsizlikler, öğretmenlerin sınıf iklimi yaratmadaki farklı yöntemleri ve buna uyum sağlayamayan çocuklara rehberlik etmek yerine, öneri olarak "eski bildiklerinizi unutun" demeleri, bilgili ve eğitimli insanların geçimlerini sağlayabilmek için zengin ama cahil insanların hizmetinde çalışmak zorunda kalmaları ve her türden şiddet, çocuklar tarafından ustalıkla çözümlenmekte ve bu iki yüzlü tutum eleştirilmektedir. Mektuplarda Ahmet ile Zeynep'in sıkça şikâyet ettikleri konuların başında büyüklerin çocuklara yönelik tutarsız tavırları gelir. Örneğin Ahmet fedakârlık gibi pek çok evrensel değerin büyükler tarafından çocuklara yanlış anlatıldığını belirtir (Nesin, 2008: 51). Yine Ahmet en sevmediği huyun çocuklara "sen anlamazsın" denilerek gerçeklerin ört bas edilmesi ya da önemsizleştirmesi olduğunu vurgular (Nesin, 2008: 82). Mektuplarda sıklıkla her iki çocuk tarafından büyüklerin çocuklara düzenli olmak, tutumlu olmak gibi olumlu davranış kalıplarını dikte ettikleri ancak kendilerinin bu davranışları pek sergilemedikleri hususu eleştirilir.

\section{Şimdiki Çocuklar Hâlâ Harika}

Zehra İpşiroğlu'nun ilk baskısı 1967 yılında yapılan Aziz Nesin'in Şimdiki Çocuklar Harika kitabına nazire niteliğinde yazmış olduğu Şimdiki Çocuklar Hâlâ Harika adlı eserinde yine babasının işi nedeniyle Fethiye'ye taşınan Doğan ile İstanbul'daki arkadaşı Deniz arasındaki e-postalar söz konusu edilmektedir. Eserin tamamı yetmiş altı e-posta metninden oluşmaktadır. E-postaların günümüzde mektupların yerini aldığı gerçeğinden hareket edersek Şimdiki Çocuklar Hâlâ Harika adlı eserin de bir nevi çocuk "mektup" romanı olduğunu kabul etmek gerekecektir. İpşiroğlu eseri yaratıcı okuma alt başlığı ile sunmuş ve "Bu kitap çocuk eğitiminde gerekli sanılan, günümüzde geçerli birtakım değer yargılarının yanlışlığını anlatıyor", diyerek eserin yaratıcılık boyutunun yanına eleştirel boyutu da eklemiştir. İşiroğlu eserinde Aziz Nesin'in karakterleri Ahmet ile Zeynep'in kendi eserindeki Deniz'in anne ve babası olduğunu belirterek iki kitap arasında bağ kurmakta ve bir nevi nehir roman bağlamı yakalamaya çalışmaktadır. Dolayısıyla Aziz Nesin'in eserindeki mizahi eleştirel üslubun İpşiroğlu'nun eserinde de devam ettirildiği görülür. Deniz'in babası çalıştığı kurum olan üniversiteyi "bilgi belletme ve tüketme merkezi" olarak nitelemektedir. Deniz anne ve babasının sürekli meşgul olduklarını, toplumsal konulardaki duyarlılıklarını evdeki çocuklarına yansıtmadıklarını, gazeteci olan annesini eleştirerek vurgular: "Annem insan hakları, kadın hakları, çocuk hakları diye koşturup durmaktan başını derde sokacağına, azıcık da benim haklarımı düşünmeli diyorum. Burası Mac Donalds değil, ben de çocuk köle değilim" (İpşiroğlu, 2019: 24).

Doğan ise dedesi ve babasından hareketle büyüklerin tezat içeren/tutarsız disiplin yaklaşımlarından şikayetçidir: "Disiplin olmadı mı karmaşa çıkar. Karmaşa çıktı mı evin huzuru kaçar. Her şeyin başı disiplin. İyi hoş da onun disiplinden anladığı yalnızca kendi dediğinin yapııması. Bunu ona söylediğimde, "Elbette ki benim dediğim olacak ailenin reisi benim!" diyor. Ben karar verdim, büyüyüp de evlendiğimde kesinlikle ailenin reisi olmayacağım" (İpşiroğlu, 2019: 64).

Doğan'ın anne ve babalarının tutumundan şikâyetçi tüm çocuklar gibi Deniz'e yaptığı teklif de ironik bir kılıf içermektedir: "Bir süre ailelerimizi değişmeye ne dersin? Keşke çocukların da ailelerini boşama hakkı olsa. Hiç olmazsa bir süre için" (ipşiroğlu, 2019: 133).

Eleştiri konusu olan bir diğer başlık ise elbette eğitim sistemidir. Öğretmenler, eğitim modelleri ve ölçme değerlendirme araçları sıklıkla eleştiri konusu edilmektedir. Deniz "Arıtma sistemini çalıştırmayı ve başta seri tüketim malı öğretmenler olmak üzere hoşuma gitmeyen kim varsa bir bir değiştirmeyi denedim ama tek başıma beceremedim" (Ipşiroğlu, 2019: 102) der. Yine Deniz "ilkönce okuldaki dersler için gereken tüm bilgileri depolayan bir bilgi tüpü icat edeceğim. Bu tüp toplu iğne büyüklüğünde, görünmeyecek bir biçimde okul üniformasının yakasına takılıyor. Böylece ders çalışma derdinden de sonsuza kadar kurtulmuş olacağım" (Ipşiroğlu, 2019: 140) diyerek sarsıcı çözümlerine yeni bir örnek daha ekler. Bunların yanı sıra mektuplarda akran zorbalığı, toplumsal cinsiyet kodları, büyüklerin ikircikli tutumu eleştirilen diğer konulardır. Eserin mektuplar yerine mektubun çağdaş 
mirasçısı e-postalar aracılı̆̆ıyla yazılması yazarın günümüz çocuk okurunun eğilimlerini dikkate aldığını göstermektedir. Ancak e-posta atası mektubun yerini doldurmakta henüz çok da mahir değildir: "Zira mektup, bugün bilgisayar yahut cep telefonu aracılı̆̆ıyla kullandı̆̆ımız adlarıyla e-posta,skyp,cahat,msn gibi araçlardan farklı olarak insanın kendini derinlemesine ifade edebilmesine, yalnızken; muhataptan uzaklardayken kaleme alındığından, karşımızdakinin halinin ve tepkisinin bilinmezliğinin de doğurduğu merak, endişe, umut gibi duyguların da ifade edilebilmesine imkân tanıyan bir araçtı. Kanaatimce mektubun kağıt ve kalemden sonraki temel malzemesi ise "hasret"ti" ( Abak, 2006: 107).

\section{Mektup Türündeki Çeviri Çocuk Edebiyatı Ürünleri}

Bill Adler'in editörlüğünü yaptığı Çocuklardan Harry Potter’a mektuplar ile Eric Marshall ve Stuart Hample tarafından bir araya getirilmiş olan Çocuklardan Tanrıya Mektuplar adlı eserler çocukların belirli bir tema etrafında yazdıkları mektupların yazarlar tarafından derlenmesiyle oluşturulmuştur. Bu nedenle bu tür kitapların birer mektup antolojisi/derlemesi olduğunu belirtmek doğru olacaktır. Çocuk Kalbi ise mektup roman türünde kaleme alınmış bir çeviri eserdir.

\section{Çocuklardan Harry Potter'a Mektuplar}

Amerika, Avustralya, Güney Afrika, Kanada, Filipinler, İrlanda, Almanya, Hollanda, Singapur, Yeni Zelanda, Estonya, Hindistan, İngiltere, Kosta Rica ve Endonezya'da yaşayan çocuklar tarafından yazılan toplam yüz seksen bir mektup, izci kulüpleri, yayınevleri ve öğretmenler aracılığıyla toplanmış ve Bill Adler editörlüğünde bir araya getirilerek Çocuklardan Harry Potter'a Mektuplar adlı bir eser orta çıkarılmıştır. Bu çalışmada beş yaşından yirmi iki yaşına kadar çocuk ve genç pek çok yaş gurubundan kişinin Harry Potter 'a mektuplar göndermesi, aslında serinin her yaş grubunda severek okunduğunu gösteren önemli bir işarettir. Son zamanlarda en çok okunan çocuk kitaplarından biri olarak kabul edilen serinin evrensel ölçekte bu kadar ilgi görmesinin en önemli sebebi eserin taşıdığı fantastik kimliktir. Gerçek dünyanın katı, sıkıcı ve adaletsiz kuralları arasına sıkışan çocuklar için benzer engellere fantastik bir dünyada savaş açmış olan Harry Potter, gerçek bir kahraman hükmündedir. Harry Potter serisinin çocuk edebiyatı ilkelerine ne kadar uygunluk taşıdığı tartışılmakla birlikte çocukların bu konuda akademisyenlerden ve öğretmenlerinden farklı düşündükleri de ortadadır. Mektupların çok geniş bir coğrafyadan elde edilmesi Harry Potter serisinin farklı dillerden, farklı ülkelerden pek çok çocuk tarafından sevilerek okunduğunu ortaya koymaktadır.

Zaten Adler eserin son bölümünü Harry Potter üzerine çocuklarla yaptığı 45 röportaj metnine ayırmıştır. Bu bölümde Adler çocuklara Harry Potter kitabının okuma alışkanlıklarına bir katkı sağlayıp sağlamadığını sormuş ve çocukların büyük bir bölümünden de olumlu yanıt almıştır. Adler kitabın neden bu kadar sevildiği yönündeki sorusuna ise daha çok eserin fantastik yönüne vurgu yapan yanıtlar almıştır. Bu durum da yukarıdaki görüşü destekler niteliktedir. Belki artık akademisyenlerin, eğitimcilerin ve velilerin de verili değerler üzerinden değil de çocuğun gözünden dünyaya bakmalarının zamanı gelmiştir.

Eserde dikkat çeken önemli noktalardan biri de mektup yazarı kız çocukların Harry'den ziyade serinin kız karakteri Hermione'yi kendilerine özdeşim unsuru olarak seçmeleridir. Bu cinsiyet ve özdeşim değişkenleri arasındaki bağlantıyı açıklaması açısından önemlidir. Eserde özellikle yaş grubu küçüldükçe mektup yazarı çocukların Harry Potter'dan öğretmenleri için büyü tarifleri istemeleri gibi mizahi ama çocuk için anlamlı gerçeklere tesadüf etmek de mümkündür. Ancak çocukların pek çoğunun Harry'nin yardımsever, iyi kalpli, dürüst ve akıllı olduğu yönündeki kişilik özelliklerini vurgulaması, eserin çocuklara değer öğretimi açısından yarar sağladığının ve karakter gelişimlerine katkıda bulunduğunun bir göstergesidir. Sever de çocukların kitap kahramanlarına öykünme ve özdeşim kurmalarının birçok getirisi olduğundan söz etmektedir: "Okuduğu ya da dinlediği bir öykünün kahraman ya da kahramanlarıyla kurduğu etkileşim, çocuğun yeni düşsel arkadaşlar edinmesini sağlar. Kendi gibi duyan, düşünen ve hareket eden ya da etmek isteyen başka çocukların da olduğunu ya da olabileceğini anlar. Güven duygusunu geliştirir. (...) Çocuk kitaplarında, çocukların yeni yaşantılar kazanmalarına olanak sağlayan en temel öğelerden biri de öykündükleri kahraman/kahramanlar ve onların nitelikleridir. Kahramanların fiziksel ve ruhsal özelliklerinin abartıya kaçılmadan iyi geliştirilmiş olması, karşılaştığı sorunları çözmedeki kararlılığı, amaca ulaşmada izlediği yöntemlerin niteliği ve bu 
eylemler bileşkesinin söz ve davranışlarla somutlanması, çocukları da kahraman gibi duymaya, düşünmeye ve hareket etmeye istekli kılar" (2003: 64-65).

\section{Çocuk Kalbi}

Edmondo De Amicis'in Çocuk Kalbi adlı kitabında dokuz yaşındaki Enriko'ya annesinin, babasının ve kız kardeşinin yazdığı toplam on mektuba yer verilir. Aynı çatı altında yaşayan aile üyeleri mektubu aile içi ilişkileri düzene koymak için bir iletişim aracı olarak kullanmışlardır. Mektupların ana konusunu Enriko'nun uygunsuz davranışları ve aile üyelerinin bu yöndeki uyarıları ve ondan beklentileri oluşturmaktadır. Mektuplarda ele alınan konular sosyal ve ekonomik adaletsizlikler ve bunlara maruz kalan insanlara karşı duyarlı olma, anne sevgisi, öğretmen sevgisi, vatan sevgisi, ulus bilinci ve eğitimin önemidir (Amicis, 1998: 29-30, 47, 211-212). Kitap çocuğun ev ve aileden başlayarak okul ve iş hayatı gibi yakın ve uzak çevresiyle olan iletişimindeki hataları ve doğru davranışları göstermesi bakımından eğiticidir.

Çocuk Kalbi'nde mektuplara kurgu izin verdikçe yer verilmiştir. Roman kurgusu içerisine mektupların dahil edilmesi çoğul bakış açııının yakalanmasına olanak sağlamaktadır. Ayrıca mektuplar içerdikleri öznel ve samimi anlatım nedeniyle roman kişilerinin dünyasına okurun daha teklifsiz dahil olmasına olanak sağlamakta ve eserin merak duygusunu artırmaktadır. Bu durum karakteri yazarın hakimiyetinden kurtardığı için okur açısından kahramanla özdeşim kurma ve empati becerilerini de geliştirmekte, özellikle çocuk okurların dünyayı ve insanı algılama yönelimini desteklemektedir (Tekin, 2013: 246).

\section{Çocuklardan Tanrıya Mektuplar}

Çocuklardan Tanrıya Mektuplar mektup derlemesi biçiminde oluşturulmuş bir diğer eserdir. Eserin adı ilk başta mizahi bir çağrışım yapsa da kitap aslında çocukların inanç cephelerini anlamak noktasında yetişkinlere yardımcı olmaktadır. Mustafa Ökkeş Evren ve Kerim Yavuz gibi birçok araştırmacı inanç konusunda çocukta doğuştan bir eğilim olduğu yönünde görüş belirtmektedirler. Buna göre çocuk yaratılış itibariyle kendini koruyacak, güveneceği bir gücün var olduğuna inanmaya meyillidir. Zaman içinde çocuğun çevreden öğrendikleri ve kendi gözlemleriyle yaratıcı kavramını şekillendirmesi mümkündür (Evren, 2005, 309; Yavuz, 1987, 273-278). Ayrıca Yavuz, çocuğun Tanrı ve din anlayışı ile yetişkinlerin yaklaşımları arasında da fark olabileceğini belirtir: "Şunu unutmayalım ki çocuğun oluşmakta olan dini, sadece ana-baba dindarlığının çocuklara kuru bir şekilde aktarılması değildir. Çocuk dini; yalnızca yetişkinlerin dinine bağlanamaz. Çünkü çocuk dindarlığı inanma yönünden değil, yetişkinlerin dininden inanç keyfiyeti bakımından farklıdır" (Yavuz, 1987: 274). Kısacası çocuğun inancı içten ve doğaldır. Kurallara ve biçimlere tabi değildir.

Eseri yayıma hazırlayan Stuart ve Marshall da eserin önsöz bölümünde benzer bir saptamada bulunmaktadırlar: "Kitaptaki mektupların tümü büyük bir güven duydukları ve umutla bağlandıkları tanrıya yazıımış. Ama kendilerinin tanımladığı, büyükler dünyasınca henüz biçimlendirilmemiş tanrıya. Onların, çocukların tanrısına..." (Marshall, Stuart; 2005:3).

Eser sekiz bölümden oluşmakta ve okul öncesi ve ilkokul döneminde bulunan çocukların Tanrı'dan talep ettikleri dilekler ve istekler, Tanrı'ya yönelik eleştirileri, övgüleri ve itirafları çerçevesinde yazılmış mektuplarından oluşmaktadır (Marshall, Stuart, 2005:8-24). "istekler" adını taşıyan ilk bölümde çocukların Tanrı'dan bisiklet, eldiven gibi basit gündelik eşyaların yanı sıra, yılan olmak, köpekleri insanlar gibi uzun ömürlü yapmak gibi istekleri de bulunmaktadır. Bunun dışında bazı çocukların kendilerini erken yatıran ya da çok sinirli olan babalarını değiştirmesi için Tanrı'dan ricada bulundukları görülmektedir. "Eleştiriler" (Marshall, Stuart: 2005: 35-54) bölümünde ise "Sevgili Tanrı, eğer hiç kimse bilmeyecekse iyi olmanın ne yararı var!" (Marshall, Stuart, 2005: 50) gibi serzenişlere rastlanmaktadır. "itiraflar" (Marshall, Stuart, 2005: 56-69) bölümünde çocukların en değerli sırlarını Tanrı ile paylaştıkları görülmektedir. Örneğin "Sevgili Tanrı, küçükken yaptığım kötü şeyler için pişmanım" gibi oldukça masum itiraflar bu bölümde yer almaktadır. "Önemli Sorunlar" (Marshall, Stuart, 2005: 76-96) bölümünde çocukların baş edemedikleri problemler konusunda Tanrı'ya yazdıkları mektuplar ve çözüm istekleri bulunmaktadır. Bunlar arasında çocukların yapmakta zorlandıkları ödevler, meslek seçimleri, evlenme, doğum gibi yaşamın çeşitli dönemlerine ait sorgulamaları yer 
almaktadır. "Kitap Hakkında" (Marshall, Stuart, 2005: 97-120) bölümünde ise çocukların çeşitli doğa olayları hakkındaki soruları (Güneş neden geceleri yok oluyor? Neden ölüyoruz? Ağaçların boyu neden insanların boyundan daha uzun? Günler neden kısalıyor ve sonra uzuyor? Gökyüzü neden mavi, otlar neden yeşil?... gibi) yer almaktadır. Kitabın son bölümü Övgüler'de (Marshall, Stuart, 2005: 122-127) ise çocukların Tanrı'nın takdir ettikleri yönlerini ve ona olan sevgilerini içeren mektuplara yer verilmiştir. Bu mektupları yazan çocukların yaşları ve ülkeleri ile bu mektupların nasıl bir araya getirildiği konusunda bilgi verilmemiştir.

\section{Sonuç}

Araştırmanın inceleme nesnelerini oluşturan eserlerde eğiticilik yönü ağır basmaktadır. Çocuklarda doğru davranış kalıpları oluşturmak, çevrelerine, ülkelerine ve dünyaya karşı sorumluluk duygusu taşıyan bireyler yetiştirmek tüm eserlerin ortak amacıdır. Bu durum mektup derlemeleri biçiminde düzenlenmiş Çocuklardan Tanrıya Mektuplar ve Çocuklardan Harry Potter'a Mektuplar 'da ilk bakışta fark edilemese de aslında her iki eserde de çocuklara sorgulama, eleştirel düşünme, yaratıcılık gibi kazanımlar verilmeye çalışılmışır. Aynı zamanda bu iki eser çocukların duygu ve düşünce dünyalarının yetişkinlere açılması açısından da önemlidir. Çocuklardan Tanrı'ya Mektuplar aslında çok önemli bir konu olan inanç konusunun oluşumu, dini eğitim, soyut düşünme becerisi hakkında önemli ipuçları taşımaktadır. Çocuklardan Harry Potter'a Mektuplar ise çocuklarda okuma alışkanlığını geliştirme, çocukların sevebilecekleri kitaplar ve kahramanlar hakkında bilgiler içermektedir. Çalışmada çocukların fantastik türdeki kitapları okumaktan daha çok hoşlandıkları görülmektedir.

Hayvan karakterlerin ön planda olduğu eserler çevre okur yazarlığı ve eko eleştiri bağlamında çocukların farklı kazanımlar sağlamasında katkı sağlayabilirler. Özellikle Hayvanlardan Çocuklara Mektuplar I-II ile fabl türündeki eserler dünyanın sadece insanın değil, tüm canlıların anayurdu olduğunu belirtmektedir. Eser, tüm canlıların dünyanın bir parçası olduğunu ve gezegenin geleceğinin tüm canlılara değer veren bir tutumla iyiye yönlendirilebileceği yönünde mesajlar içermesi bakımından ayrıca değer taşımaktadırlar.

Annemin Mektupları, Çocuk Kalbi, Hayaletten Mektuplar (ikinci Bölüm), Gül'e Mektuplar ve Yıldızlı Masallar ise aile içi iletişimin önemi, aile bağlarının güçlendirilmesi, ailenin değeri gibi konularda içerdiği mesajlar açısından önem taşımaktadır. Hayaletten Mektuplar (Birinci Bölüm), Dolunay Dedektifleri/Dehşet Mektuplar II, Şimdiki Çocuklar Harika ve Şimdiki Çocuklar Hâlâ Harika ise arkadaşlığın değeri ve uzaktaki arkadaşlarla iletişimin sürdürülmesi konusunda değerli düşünceler taşıyan eserlerdir.

Örneklemi oluşturan eserler ölçeğinde konuya bakıldığında dikkat çeken bir diğer nokta ise çeviri ve yerli eserler arasındaki yaklaşım farklılı̆ıdır. Yerli ürünler anlatıcı ve hedef kitle açısından değerlendirildiğinde daha çok didaktik ve öğüt verici bir nitelik taşımaktadır. Özellikle anlatıcı özne pek çok eserde yetişkinler/kimi zamanda hayvan karakterler olduğundan hedef kitle olan çocuklara sürekli olarak toplumsal ya da evrensel düzeyde davranış kalıplarını aktaran öğütlerin verildiği dikkat çeker. Bu durum çocuk edebiyatı ilkeleri açısından pek de onay gören bir yaklaşım değildir. Zira amaç ders vermek, öğüt vermekten ziyade kurmaca ya da gerçek bir atmosfer içerisinde çocuk okurun donanımına göre kendi sonucunu kendinin çıkarmasının sağlanması olmalıdır. Ancak yerli yazar örneklemi içerisinde Aziz Nesin'in ve Zehra İpşiroğlu'nun eserlerinde yetişkin dünyasının çocuğa sürekli parmak sallayan, ders veren ancak bunları kendi yaşamlarında uygulamayan tutumuna yönelik oldukça ironik yaklaşımların bulunduğu da dikkat çekmektedir. Bu durum Aziz Nesin'in mizahi tutumuyla, Zehra İşiroğlu'nun ise hem eserini Şimdiki Çocuklar Harika adlı esere nazire olarak yazmasından hem de kendisinin çocuk edebiyatı alanında akademik çalışmalar yapması nedeniyle çocuk gerçekliğini daha iyi tanımasından kaynaklanıyor olmalıdır. Ayrıca her iki eserde de anlatıcı öznelerin çocuklar olması da anlatım dilindeki bu yaklaşım farkını açıklamak açısından önemlidir.

Çeviri eserlerde bu slogancı tutumun yerini daha eğlenceli bir anlatıma bıraktığı, daha çok mizahi bir yaklaşımın benimsendiği görülür. Ancak Çocuk Kalbi adlı eserde de yerli eserlerde olduğu gibi mektup yazarlarının yetişkin olmalarından (anne, baba... vb.) kaynaklı olarak öğüt verici ve didaktik bir anlatımın varlığı dikkat çeker. 
Bu durum mektupların anlatıcı öznelerinin niteliği açısından yeniden gözden geçirilmesini zorunlu kılmaktadır. Yerli eserler örneklemi açısından meseleye bakıldı̆̆ında Şimdiki Çocuklar Harika ve Şimdiki Çocuklar Hâlâ Harika adlı eserler dışındakilerin anlatıcı öznelerinin yetişkinler olduğu görülür. Bu sonuç da ürünlerdeki öğretici ve öğüt verici anlatımın nedenini açıklar niteliktedir. Yetişkin dünyası çocukları sürekli olarak dünyaya uyum sağlaması gereken varlıklar olarak düşündüğünden böyle bir tutum geliştirmiştir. Ancak yerli örneklem içerisinde Hayvanlardan Çocuklara Mektuplar I ve II adlı eserlerde de hayvan anlatıcı öznelerin dilinden öğüt verici, doğru davranış kalıplarını iletici bir dilin varlığının devam ettirildiği görülür. Burada da anlatıcı özneler her ne kadar hayvan karakteristiğinde olsalar da yetişkin tutumunu sahiplenmişlerdir. Bu noktada, bir etken olarak doğu ve batı dünyasının çocuk yetiştirme kodlarının farklılığının da anlatım dilini etkilediğini söylemek mümkündür. Bu durum, Türk toplumun çocuklarına karşı daha koruyucu/kollayıcı ve aktarım merkezli yaklaştığı, batı yaşam biçiminde ise çocuğun kendi öğrenmelerinin daha değerli olduğu ve yazarların da bu kültürlere ait birer birey olarak eserlerindeki anlatım dilinin bundan etkilenmiş olduğu gerçeğini kabul etmemizi olanaklı kılar.

Örneklemi oluşturan eserlerden hareketle mektup türünün mizah, ironi, fantastik, didaktik, eleştirel pek çok dil ve anlatım biçimiyle de rahatlıkla kullanılabildiği görülmektedir. Bu durum, çocuğun dünyasına farklı yollarla ulaşılmasını, anlatı katmanlarının artırılmasını ve çocuğun çok yönlü düşünebilmesini sağlamak açısından yazara pek çok olanak da sunmaktadır. Bu konuda, "mektubun" eserlerde bir tür olarak mı, yoksa bir teknik olarak mı yer aldığı meselesi de biraz muğlak kalmaktadır. Çünkü her çocuk eseri baştan sona mektuplardan oluşmamakta, zaman zaman mektup kurgunun bir parçası haline gelerek türden çok teknik özelliği ile esere katkı sağlamaktadır. Aslında bu yapıdaki anlatı örneklerini karma anlatılar ya da karma türler olarak da adlandırmak mümkündür. Bu açıdan, çocuk edebiyatı sahası içerdiği karma türler ve/veya melez türler açısından geniş çaplı bir araştırma havuzu üzerinden incelenmelidir. Zira bugüne kadar çocuk edebiyatındaki karma ya da melez türler üzerine yapılmış çalışmalar bulunmamakta, özellikle güncel çocuk edebiyatı içerisinde yer alan klasik türlerin dışında oluşan/oluşmakta olan yeni türlerin incelenmesine öncelik verilmemektedir.

Sonuç olarak, örneklemi oluşturan eserlerde mektubun içerdiği içten ve öznel anlatım sayesinde çocukların verilen mesajları dolaysız olarak değerlendirmeleri sağlanmıştır. Eserlerde uzaktaki yakınlarla, dostlarla haberleşmenin önemi anlatılmış, sevgiyi ifade etmenin mektupla da mümkün olduğu vurgulanmıştır. Ayrıca mektup romanların çoklu bir anlatıcı kadrosuna sahip olmaları farklı görüşlerin, kültürlerin, yaklaşımların bu tür eserlerde çoğulcu ve demokratik bir bakış açısı aracılığıyla aktarılmasını olanaklı kılmıştır. Mektup, çocuğun kendine doğru çıktığı keşif ve anlama yolculuğunda içten ve kişisel bir tür olması bakımından ona rehberlik edecek elverişli bir malzemedir. Mektup türü tüm bu özellikleri sayesinde çocukların yazma becerilerinin geliştirilmesine de katkı sunacaktır.

\section{Kaynaklar}

Adler, B. (2006). Çocuklardan Harry Potter'e mektuplar. İstanbul: Pegasus Yayınları.

Abak, Ş. (2006). Mektuptan e-postaya. Hece Dergisi Mektup Özel Sayısı, 114-115-116, 106-109.

Argunşah, H. (1996). Ziya Gökalp’ın Limni ve Malta mektuplarında aile, kadın ve çocuk eğitimi fikri.

Erciyes Üniversitesi Sosyal Bilimler Enstitüsü Dergisi, 7, 247-263.

Baş, B. (2003). Altıncı sınıf Türkçe ders kitaplarındaki metin türleri üzerine bir inceleme. Türklük Bilimi Araştırmaları, 13 (2003 Bahar), 257-265.

Çelikler, Ç. (2010). Hayvanlardan çocuklara mektuplar I. İstanbul: ikinci Adam Yayınları.

Çelikler, Ç. (2010). Hayvanlardan çocuklara mektuplar II. İstanbul: İkinci Adam Yayınları.

Çerçi, A. (2019). Çocuk ve mektup. Okuma Yazma Eğitimi Araştırmaları, 7(1), 15-24.

De Amicis, E. (1998). Çocuk kalbi. Ankara: Sel Yayıncılık.

Donbay, A. (2011). Edebiyatımızda 'mektup' türü ile ilgili başlıca çalışmalar" Erdem Dergisi, 61, 83-102.

Energin Usta, A. (2010). Namık Kemal'in mektupları ve çocuk. Uluslararası Namık Kemal Sempozyumu’nda sunulmuş sözlü bildiri. Namık Kemal Üniversitesi, Tekirdağ.

Evren, M. Ö. (2005). Çocuk edebiyatında dinî yaklaşım. Hece Dergisi Çocuk Edebiyatı Özel Sayısı, 104105, 309-314. 
İpşiroğlu, Z. (2019). Şimdiki çocuklar hâlâ harika. İstanbul: Çınar Yayınları.

Karakuş, H. (2009). Annemin mektupları. Ankara: Bilgi Yayınevi.

Kefeli, E. (2002). Bir anlatım tekniği olarak mektup. İstanbul: Kitabevi Yayınları.

Marshall, E.,\& Hample, S. (2005). Çocuklardan Tanrıya mektuplar. İstanbul: Bulut Yayınları.

Nesin, A. (2008). Şimdiki çocuklar harika. İstanbul: Nesin Yayınevi.

Sever, S. (2003). Çocuk ve edebiyat. Ankara: Kök Yayıncılık.

Sınar Çılgın, A. (2007). Çocuk edebiyatı. İstanbul: Morpa Kültür Yayınları.

Şimşek, T. (2004). Çocuk edebiyatı. Erzurum: Suna Yayınları.

Tansel, F. A. (1965). Ziya Gökalp külliyâtı-II: Limni ve Malta mektupları. Ankara: Türk Tarih Kurumu Basımevi.

Tansel, F. A. (2013). Namık Kemal'in husûsî mektupları-II: Istanbul ve Midilli mektupları-I. Ankara: Türk Tarih Kurumu Yayınları.

Tekin, M. (2013). Roman sanatı I-romanın unsurları. İstanbul: Ötüken Neşriyat.

Yalçın, H. (2006). Gül'e mektuplar ve yıldızlı masallar. İstanbul: Kaynak Çocuk Yayınları.

Yavuz, K. (1987). Çocukta dinî duygu ve düşüncenin gelişimi. Çocuk Edebiyatı Yıllığı 1987, 272-278.

Yener, M. (2009). Hayaletten mektuplar. İstanbul: Uçanbalık Yayınları.

Yener, M. (2010). Dolunay dedektifleri-Il: dehşet mektuplar. Ankara: Bilgi Yayınevi.

\section{Introduction}

\section{Extended Abstract}

Communication is one of the compulsory needs of human beings. People have tried different ways to convey various news, feelings and thoughts to others they cannot communicate face to face. The letter is perhaps the most advanced of these efforts. The first period letters were written in an official language rather than private. The letter is a kind that has not been processed and neglected so far in children's literature. The scarcity of letter-type works in children's literature in terms of quantity has also affected academic publications on this subject. In the context of canonical literature, it is possible to observe that the letter type is neglected compared to other types. When approaching the genre in the context of 100 Basic Works, one of the most iconic aspects of canonical literature in our country, it is seen that the situation is not in favor of the letter. That is, there are no works written in the type of letters in the Primary Education 100 Basic Works.

Among the books in the study, Letters from Animals to Children I and II, Letters to Gul and Star Fairy Tales, Letters from the Ghost, My Mother's Letters; the letters are listed in consecutively, while the letters are included in places suitable for fiction in the books of Full Moon Detectives / Terror Letters and Children's Heart. In addition to these works, the work of Aziz Nesin, which is published in 1967, was also examined. Because Zehra İpşiroğlu's work titled " The Children Are Still Great " was written in the form of a response of Aziz Nesin's book, it is a kind of continuation of Aziz Nesin's work in both form and fiction, and although the work does not comply with the historical sample filter, it is thought that it will be useful to make the evaluation subject even if it is short. In this context, it was seen that both works were a letter novel created as successive letters. As a result, together with these two works added to the study, the sample pool of the study constituted eleven works.

\section{Method}

The findings of the study are obtained by the case study method and the data is evaulated by the content analysis.

\section{Result and Discussion}

Educational aspect is dominant in the works that make up the sample. It is the common aim of all works to create the right behavior patterns in children, to raise individuals with a sense of responsibility towards their environment, country and the world. Although this situation was not noticed at first glance in the Letters from Children to God and Letters from Children to Harry Potter which are designed in the form of letter collections, in fact, in both works, it was tried to give children such as questioning, critical thinking and creativity. At the same time, these two works are also 
important for children to open their world of emotions and thoughts to adults. Letters from Children to God actually carry important clues about the formation of the subject of belief, religious education, and abstract thinking skills. Letters from Children to Harry Potter contain information about developing children's reading habits, and books and heroes that children can love. In the study, it is seen that the children like reading fantastic boks more.

Another point that draws attention when looking at the subject in the scale of the works that make up the sample is the difference in approach between translation and local works. When domestic products are evaluated in terms of narrator and target audience, they are more didactic and counseling. It is noteworthy that in many works, especially the narrator subject is adults / sometimes animal characters, the children who are the target audience are constantly given advice that conveys the behavioral patterns at the social or universal level. This is not an approved approach in terms of the principles of children's literature. Because the aim should be to give lessons, not to give advice or to make its own conclusion according to the equipment of the child reader in a fictional or real atmosphere.

Based on the works that composed the sample, it can be seen that the letter as a literary genre can be used comfortably with many forms of language and expression such as humor, irony, fantastic, didactic and critics. This situation provides many opportunities for the author to reach the world of the child in different ways, to increase the narrative layers and to enable the child to think in many ways. In this regard, the question of whether the "letter" is a genre or a technique in the works remains somewhat ambiguous. Because every child work does not consist of letters from beginning to end, it becomes a part of the letter fiction from time to time and contributes to the work with its

technical features rather than genre. In fact, it is possible to name narrative examples in this structure as mixed narratives or mixed genres. In this respect, the field of children's literature should be examined through a large-scale research pool in terms of mixed and / or hybrid genres. Because up to now, there are no studies on mixed or hybrid genres in children's literature, and it is not given priority to examine new genres that are formed / emerging outside the classical genres in current children's literature.

In addition, the fact that letter novels have a multi-narrative staff made it possible to convey different views, cultures, approaches in such works through a pluralistic and democratic perspective. The letter is a useful material to guide the child in terms of being an intimate and personal genre in his journey of discovery and understanding. Thanks to all these features, the letter genre will also contribute to the development of children's writing skills 